\title{
SISTEM INFORMASI TEMPAT PEMAKAMAN UMUM TANAH MIRING KABUPATEN MERAUKE BERBASIS WEB
}

\author{
Yosefh Salli Padang, Lilik Sumaryanti, Yuliana Kolyaan
}

Email : jhosefhpadang@gmail.com, lilik.sumaryanti@gmail.com, mariasalimubun@gmail.com Jurusan Teknik Informatika, Fakultas Teknik

Universitas Musamus

\begin{abstract}
ABSTRAK
Unit Pelaksana Teknis Dinas (UPTD) TPU Tanah Miring dalam pengelolaan makam, masih dilakukan dengan cara pencatatan dalam buku besar permohonan lahan makam serta data jenazah dan ahli waris. Banyaknya makam pada TPU tidak dapat diingat oleh penjaga makam. Hal ini membuat pihak pengelola kesulitan ketika melakukan pencarian data makam. Serta sulit bagi keluarga yang jauh ketika berziarah untuk mencari lokasi makam. Perlu dibangun sebuah sistem informasi yang dapat digunakan pihak pengelola untuk pendataan lahan pemakaman serta sistem yang dapat memberikan informasi data makam.

Pengumpulan data yang dilakukan pada penelitian ini yaitu dengan wawancara, observasi dan studi literatur dengan pengembangan sistem menggunakan metode waterfall. Bahasa pemrograman yang digunakan yaitu PHP (Hypertext Preprocessor) dan MySQL (My Structured Query Language) sebagai manajemen basis datanya.

Berdasarkan hasil pengujian sistem yang telah dilakukan dengan menggunakan metode Black box dan kuisioner, didapatkan bahwa sistem yang dibuat dapat digunakan untuk pendataan makam dan menampilkan informasi makam, serta informasi pelayanan makam pada TPU Tanah Miring.
\end{abstract}

Kata kunci: TPU, Sistem Informasi, Makam 


\section{PENDAHULUAN}

\section{Latar Belakang}

Makam merupakan bangunan dari tanah bata, batu dan kayu untuk memberi tanda pada tempat itu bahwa ada jenazah yang dikubur dibawahnya. Tempat pemakaman sebagai ruang terbuka hijau dan perlu dilakukan pengaturan mengenai pemanfaatan lahan sehingga, ruang yang digunakan memenuhi kebutuhan lingkungan. Tempat pemakaman umum (TPU) Tanah Miring adalah Pemakaman yang dibangun tahun 2016 di Kabupaten Merauke tepatnya di Distrik Tanah Miring. Luas pemakaman TPU Tanah Miring adalah 25 hektar, yang dibagi kedalam 4 blok yakni Blok Kristen, Blok Islam, Blok Campuran dan Blok Libra, dengan ketentuan lebar $=1.25 \mathrm{~m}$, panjang $=2.20 \mathrm{~m}$ dengan kedalaman $1.75 \mathrm{~m}$ (Peraturan Daerah Kabupaten Merauke No 3, 2015).

Proses perijinan untuk memperoleh lahan pemakaman, melalui prosedur dengan melengkapi syarat, bagi ahli waris yang mampu yaitu melengkapi surat permohonan memperoleh lahan makam, surat keterangan pemeriksaan jenazah dari Puskesmas atau Rumah Sakit, surat keterangan kematian dari kelurahan atau kampung setempat, selanjutnya melakukan retribusi di kantor Dinas Perumahan Rakyat dan Kawasan Permukiman bidang Pertamanan dan Pemakaman atau UPTD (Unit Pelaksana Teknis Dinas). Sedangkan untuk ahli waris yang/ tidak mampu harus menambahkan surat keterangan tidak mampu dari kelurahan, selanjutnya akan diarahkan ke Dinas Sosial untuk memperoleh surat bebas retribusi, kemudian pihak pengelola makam akan menunjukan lahan untuk melaksanakan pemakaman.
Sistem informasi adalah cara yang diorganisasi untuk mengumpulkan, memasukkan, mengolah, menyimpan, mengendalikan dan melaporkan informasi sedemikian rupa sehingga sebuah organisasi dapat mencapai tujuan yang telah ditetapkan. Dalam hal ini pengelolaan makam di TPU Tanah Miring Kabupaten Merauke masih dilakukan dengan cara pencatatan dalam buku besar permohonan lahan pemakaman, serta data jenazah dan ahli waris, Banyaknya makam pada TPU tidak dapat diingat oleh penjaga makam, sehingga membuat para peziarah ketika mecari makam masih dengan cara konvensional.

Pendataan secara manual membuat pihak pengelola kesulitan ketika melakukan pencarian data makam, serta sulit bagi keluarga yang jauh ketika berziarah untuk mencari posisi makam. Selain itu ketika melakukan pencarian posisi makam oleh ahli waris atau keluarga yang ingin berziarah, masih bertanya kepada penjaga pemakaman. sehingga dari permasalahan tersersebut dirasa perlu dibangunnya sebuah Sistem Informasi Tempat Pemakaman Umum Tanah Miring Kabupaten Merauke berbasis web. Sistem dibangun untuk membantu pihak pengelola TPU dalam mendata permintaan lahan pemakaman, mencari, melakukan pengaturan lokasi serta menampilkan informasi mengenai letak posisi makam.

Penerapan Sistem Informasi Tempat Pemakaman Umum Tanah Miring Berbasis Web, diharapkan dapat membantu untuk mengetahui dan menampilkan informasi mengenai data pemakaman pada TPU Tanah Miring. Sistem ini memberikan fasilitas pencarian posisi lokasi makam berdasarkan pencarian nama, tanggal pemakaman. 


\section{Rumusan Masalah}

a. Bagaimana membangun sebuah sistem informasi tempat pemakaman umum yang dapat membantu pihak pengelola makam untuk melakukan pendataan lahan pemakaman.

b. Bagaimana membangun sebuah sistem yang dapat menampilkan informasi makam dan letak lokasi makam

\section{Tujuan}

a. Membangun sistem informasi yang dapat digunakan pihak pengelola untuk pendataan lahan pemakaman

b. Membangun sistem informasi yang dapat memberikan informasi ahli waris dan lokasi makam

\section{TINJAUAN PUSTKA}

\section{Penelitian Terdahulu}

Sistem Informasi Geografis TPU di Wilayah Kota Palembang. Dalam penelitian ini membahas kondisi TPU yang minim perhatian dari pengawasan pemerintah kota setempat. Hasil penelitian berupa sistem informasi geografis yang dapat memberikan informasi kondisi tempat pemakaman umum dari segi tata guna lahan di wilayah kota Palembang dan memberikan informasi ketersediaan lahan tempat pemakaman umum di kota Palembang [1].

Rancang Bangun Sistem Informasi Dalam Layanan dan Pemetaan Lokasi Pemakaman Pada Pemakaman Umum di Wilayah Jakarta. Dalam penelitian ini membahas tentang penyewaan makam baru dan perpanjangan makam. Hasil penelitiannya adalah sitem informasi tempat pemakaman umum yang dapat membantu ahli waris untuk proses pemakaman, membantu pengelola TPU dalam pengelolaan makam sehingga makam lebih teratur serta membantu dalam pembuatan database baik ahli waris maupun jenazah yang lebih terstruktur, sehingga mudah di dokumentasikan [2].

Bangung Sistem Pendataan Pamakaman pada UPTD Kembang Arum Kecamatan Semarang Barat Berbasis Web. Penelitian ini membahas tentang pelaksanaan pendataan makam berdasarkan kepemilikan makam. Sistem pendataan pemakaman membantu pihak pengelola makam dan masyarakat dalam mendapatkan informasi yang jelas mengenai kepemilikan makam berdasarkan letak makam [3].

Perancangan Sistem Informasi Pelayanan Pemakaman Pada Dinas Pemakaman dan Pertamanan Kota Bandung. Dalam penelitian ini membahas tentang pelayanan perpindahan makam serta biaya pemakaman. Sistem Informasi Pelayanan Pemakaman membantu pihak pengelola makam dalam menyajikan informasi tentang ketentuan pelayanan pemakaman,perpindahan atau pembongkaran serta tarif retribusi pemakaman [4].

\section{Sistem Informasi}

Sistem informasi adalah cara yang diorganisasi untuk mengumpulkan, memasukkan, mengolah, menyimpan, mengendalikan dan melaporkan informasi sedemikian rupa sehingga sebuah organisasi dapat mencapai tujuan yang telah ditetapkan [5].

\section{Basis Data}

Basis data adalah kumpulan data yang saling berelasi antara data yang satu dengan yang lainnya, Data merupakan fakta mengenai objek orang dan lain-lain. Data dinyatakan dengan nilai angka, deretan, karakter atau symbol [6]. 


\section{Data Flow Diagram}

DFD adalah suatu model logika data atau proses yang dibuat lebih mendetail disbanding diagram konteks yang diperbolehkan, bisa dicapai dengan mengembangkan diagram. Sisa diagram asli dikembangkan ke dalam gambaran yang lebih terperinci yang melibatkan tiga sampai sembilan proses dan menunjukkan penyimpanan data dan aliran data baru pada level yang lebih rendah [7].

\begin{tabular}{|l|l|l|}
\hline No & Notasi & \multicolumn{1}{|c|}{ Keterangan } \\
\hline 1 & & $\begin{array}{l}\text { Proses atau fungsi atau } \\
\text { prosedur pada pemodelan } \\
\text { perangkat lunak }\end{array}$ \\
\hline 2 & & $\begin{array}{l}\text { Entitas luar (external } \\
\text { entity) atau masukkan } \\
\text { (input) atau keluaran } \\
\text { (output) atau orang yang } \\
\text { memakai / berinteraksi } \\
\text { dengan perangkat lunak } \\
\text { yang dimodelkan. }\end{array}$ \\
\hline 3 & & $\begin{array}{l}\text { File atau basis data atau } \\
\text { penyimpanan (storage); } \\
\text { pada pemodelan } \\
\text { perangkat lunak yang } \\
\text { akan diimplementasikan } \\
\text { denga pemrograman } \\
\text { tersturktur }\end{array}$ \\
\hline 4 & $\begin{array}{l}\text { Aliran data; merupakan } \\
\text { data yang dikirim antar } \\
\text { proses, dari penyimpanan } \\
\text { ke proses, atau dari } \\
\text { proses ke masukan } \\
\text { (input) atau keluaran } \\
\text { (output) }\end{array}$ \\
\hline
\end{tabular}

Sumber : Rosa dan Shalahuddin (2014).

\section{Entity Relational Diagram}

Entity Relationship Diagram (ERD) adalah salah satu metode yang dapat digunakan untuk menggambarkan pola hubungan yang dimiliki suatu kumpulan data. ERD ini, terdapat beberapa pola hubungan antara entity data yang ungkin terjadi,yaitu :

a. One-To-One (1-1), yaitu pola hubungan antar entity data dalam sebuah basis data yang hanya menghubungkan satu entity dengan satu entity data lain.

b. Many-To-One (M-1), yaitu merupakan pola hubungan antra entry data yang menggambarkan bahwa satu atau lebih data hanya akan terhubung dengan satu entity data tertentu.

c. One-To_many (1-M), yaitu pola hubugan data dimana terdapat suatu entity data dapat terhubung dengan satu atau lebih entity data yang lain.

d. Many-To-Many (M-M), yaitu pola hubungan data dimana terdapat satu atau lebih entity data yang terhubung dengan satu atau lebih entity data lainnya.

\section{PEMBAHASAN}

\section{Struktur Tabel Database}

Relasi antar tabel dapat dilihat pada gambar 1. Terdapat beberapa relasi yang terjadi antara tabel-tabel yang telah disebutkan diantaranya :

1. Tabel pemakaman dan tabel ahli waris.

Relasi ini dibuat karena tabel pemakaman membutuhkan kode ahli waris yang nantinya akan digunakan untuk verifikasi pendaftaran.

2. Tabel kecamatan dan tabel kelurahan.

Relasi ini dibuat karena tabel kecamatan memerlukan nama kelurahan yang berasal dari tabel kelurahan 


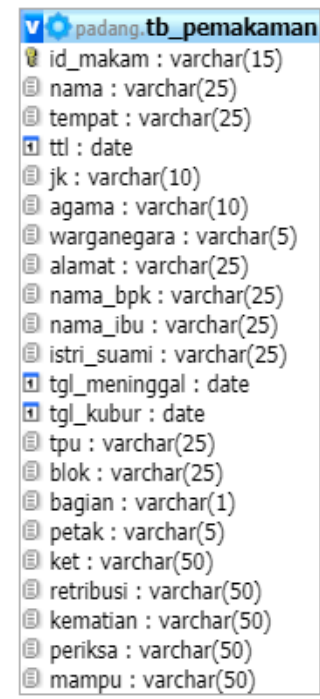

\section{Flowchart Sistem}

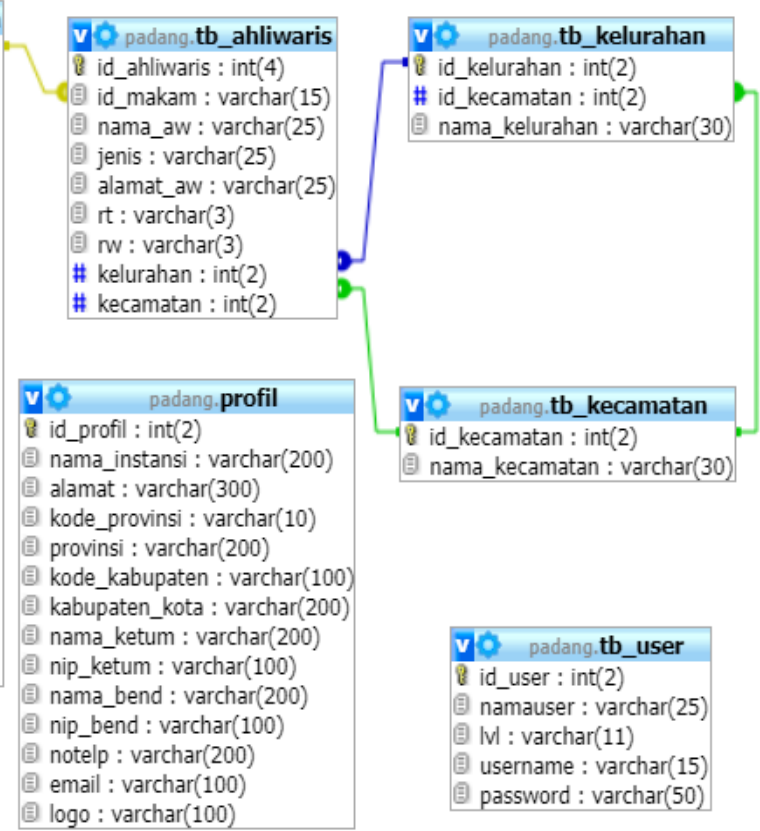

Gambar 1 Relasi antar tabel

Berikut ini merupakan flowchart sistem yang sedang berjalan untuk memperoleh lahan pemakaman.

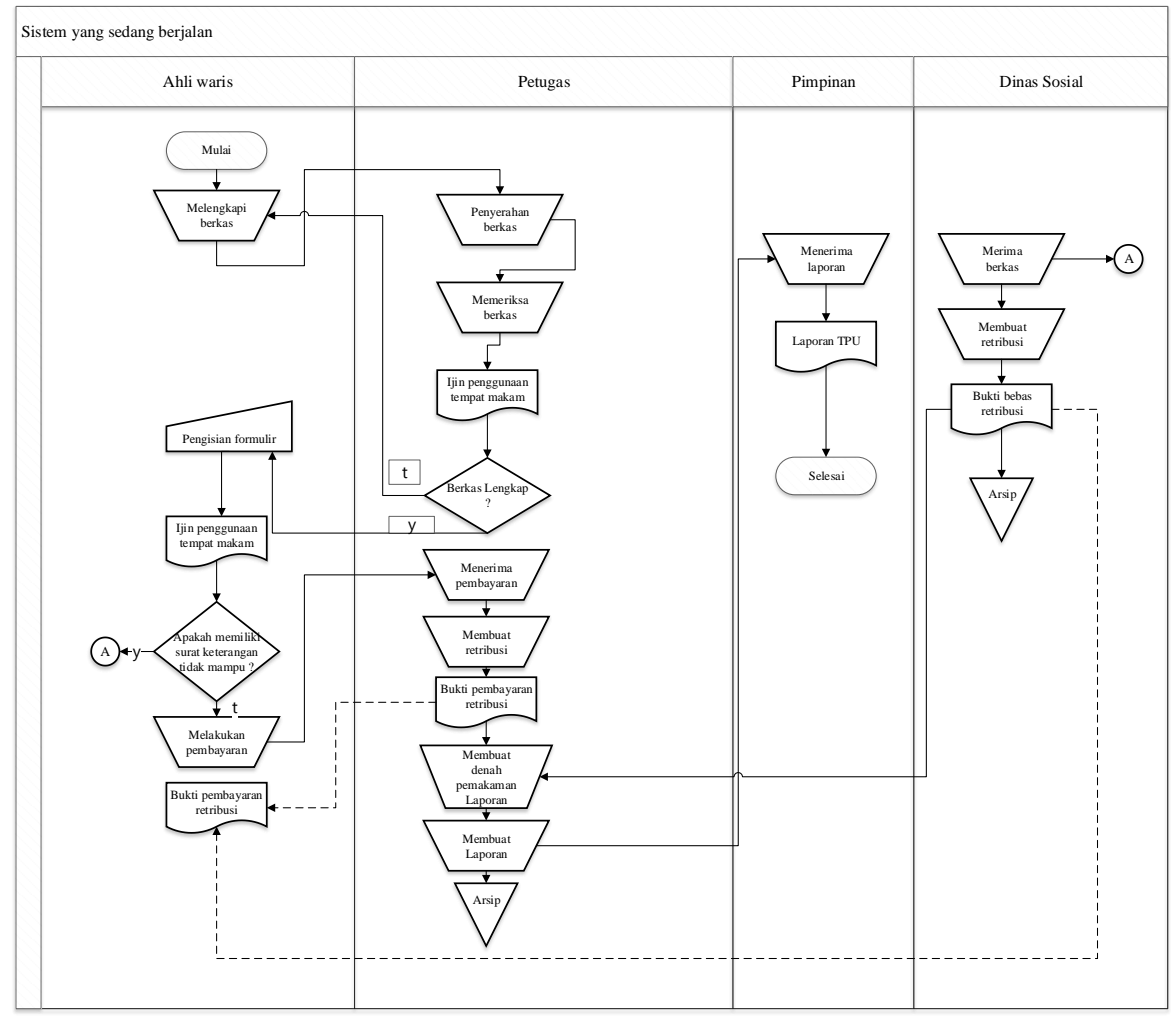

Gambar 2 Flowchart Sistem yang berjalan 


\section{Flowchart Sistem Usulan}

Berikut ini adalah flowchart sistem usulan dari sisi Petugas TPU dan admin

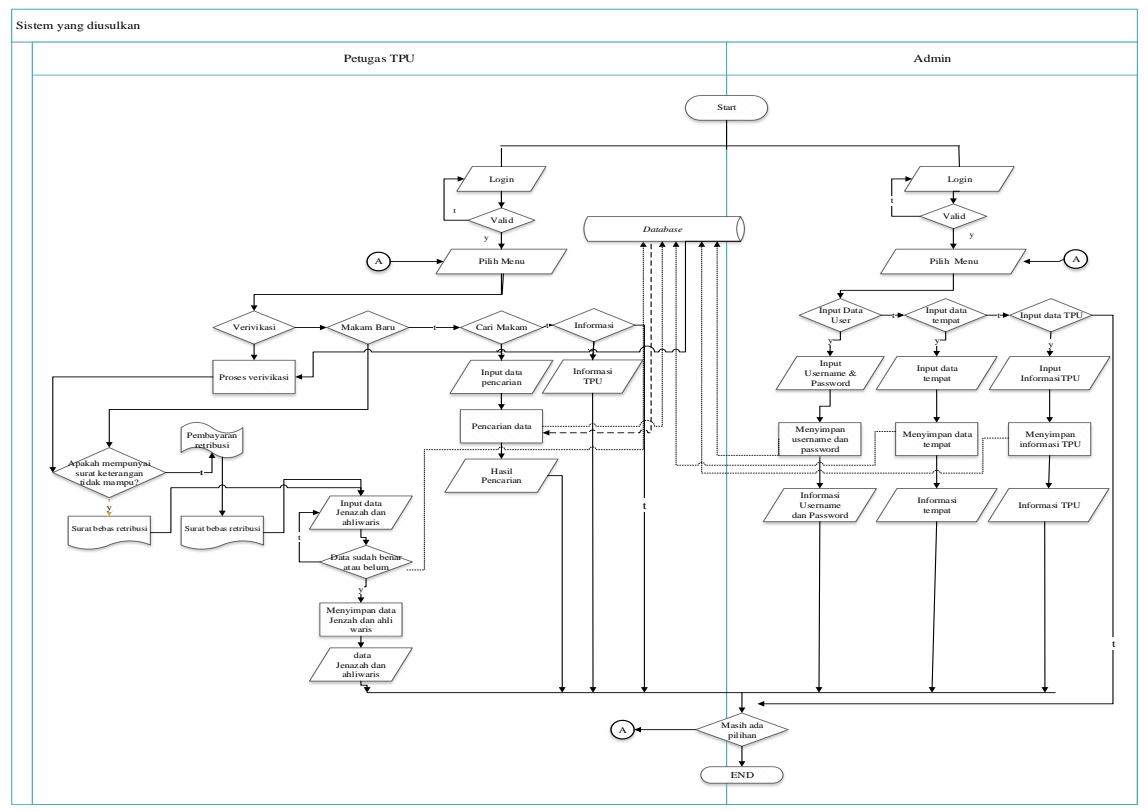

Gambar 3.1 Flowchart Sistem usulan

\section{Flowchart Lanjutan}

Flowchart dari sisi pimpinan dan masyarakat

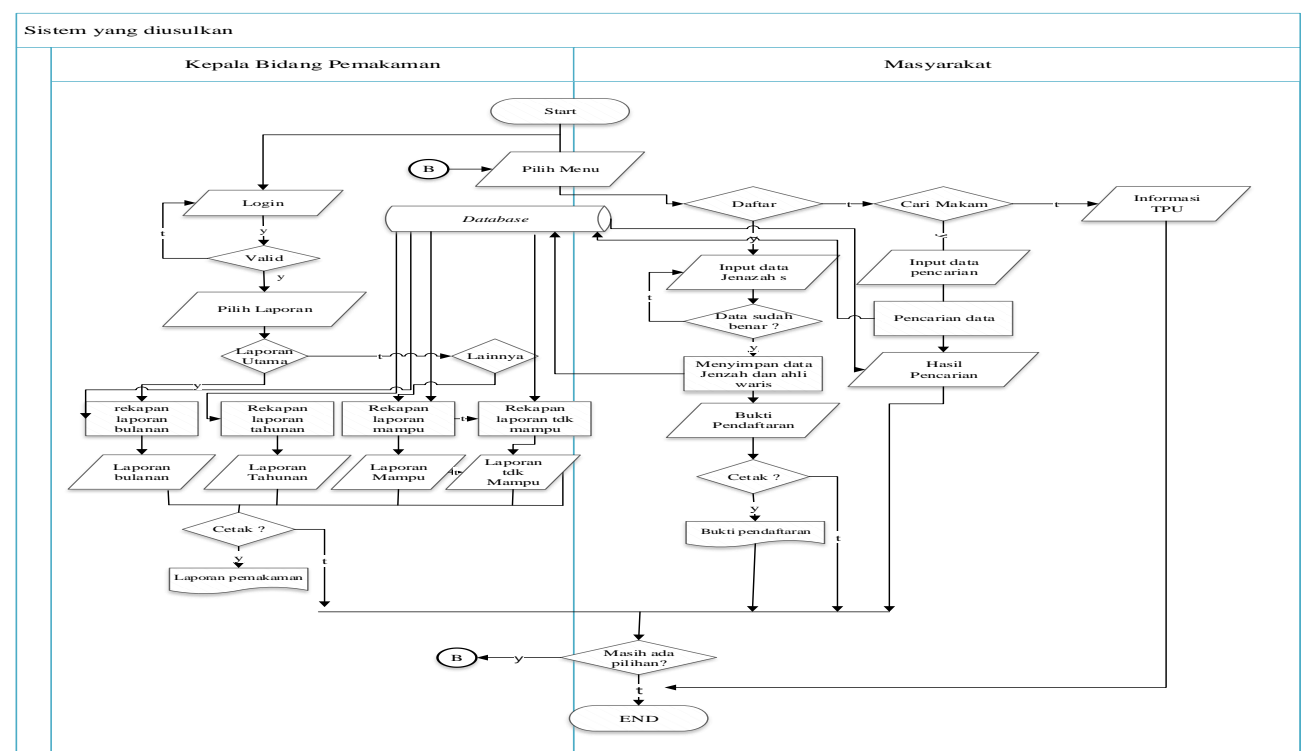

Gambar 3.2 Flowchart Sistem lanjutan 


\section{Diagram Konteks}

Diagram konteks adalah diagram yang terdiri dari suatu proses dan menggambarkan ruang lingkup suatu sistem. Admin melakukan login dan memasukan data tempat, data pimpinan, data petugas dan informasi TPU kedalam sistem yang kemudian akan diolah dan memberikan output berupa informasi data master dan informasi pemakaman.
Masyarakat mengakses sistem kemudian melakukan input data jenazah dan input data pencarian, kemudian akan diolah dan memberikan output berupa informasi data makam dan informasi hasil pencarian.

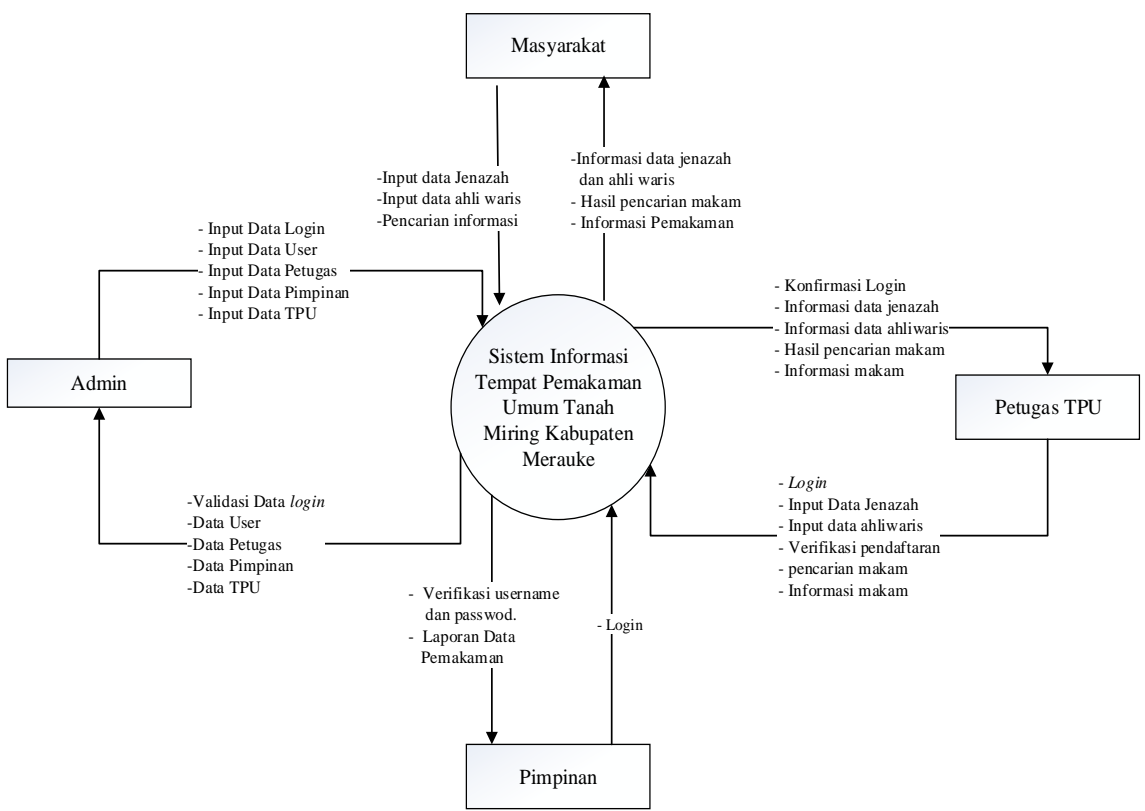

Gambar 4 Diagram Konteks

Petugas melakukan login dan melakukan input data jenaza, data ahli waris atau penanggung jawab, verifikasi pendaftaran, pencarian data makam. Kemudian data tersebut diolah dan memberikan output berupa informasi data jenazah, informasi data ahli waris atau penanggung jawab, informasi data verifikasi, informasi pencarian makam dan informasi makam.
Pimpinan melakukan login dengan melakukan input data login, kemudian dari sistem akan memberikan pilihan laporan pemakaman diantaranya, laporan tahunan, laporan bulanan, laporan bagi ahli waris yang tidak mampu dan laporan bagi ahli waris yang mampu. Diagram konteks pada sistem ini bisa dilihat pada gambar berikut ini 


\section{DFD Level 0}

DFD dapat dilihat pada gambar 6 . DFD level 0 merupakan penjabaran dari diagram konteks yang telah dirancang sebelumnya. Deskripsi DFD level 0 :

a. Proses 1.0

Proses 1.0 diberi nama login yang merupakan proses untuk mengakses sistem yang dimana inputannya berupa username dan password serta output berupa konfirmasi login.

b. Proses 2.0

Proses 2.0 diberi nama manajemen data master yang inputannya berupa data user, data Kecamatan, Data Kelurahan, dan profil. Output dari Inputan ini adalah berupa informasi User yang terdiri dari Pimpinan, dan petugas, Informasi Lokasi, serta Informasi TPU.

\section{c. Proses 3.0}

Proses 3.0 diberi nama Pendaftaran yang inputannya berupa data Jenazah dan Ahli waris serta output yang dihasilkan adalah informasi pendaftaran Jenazah.

\section{d. Proses 4.0}

Proses 4.0 diberi nama verifikasi yang inputannya berupa data Pendaftaran Makam. Output yang dihasilkan adalah informasi permintaan pelayanan.

e. Proses 5.0

Proses 5.0 diberi nama mengelola laporan yang inputannya berupa data Jenazah dan Ahli waris output yang dihasilkan adalah laporan Pemakaman.

\section{Proses 6.0}

Proses 6.0 diberi nama Info Makam yang inputannya berupa Pencarian data Jenazah dan Ahli waris untuk mengetahui informasi letak makam.

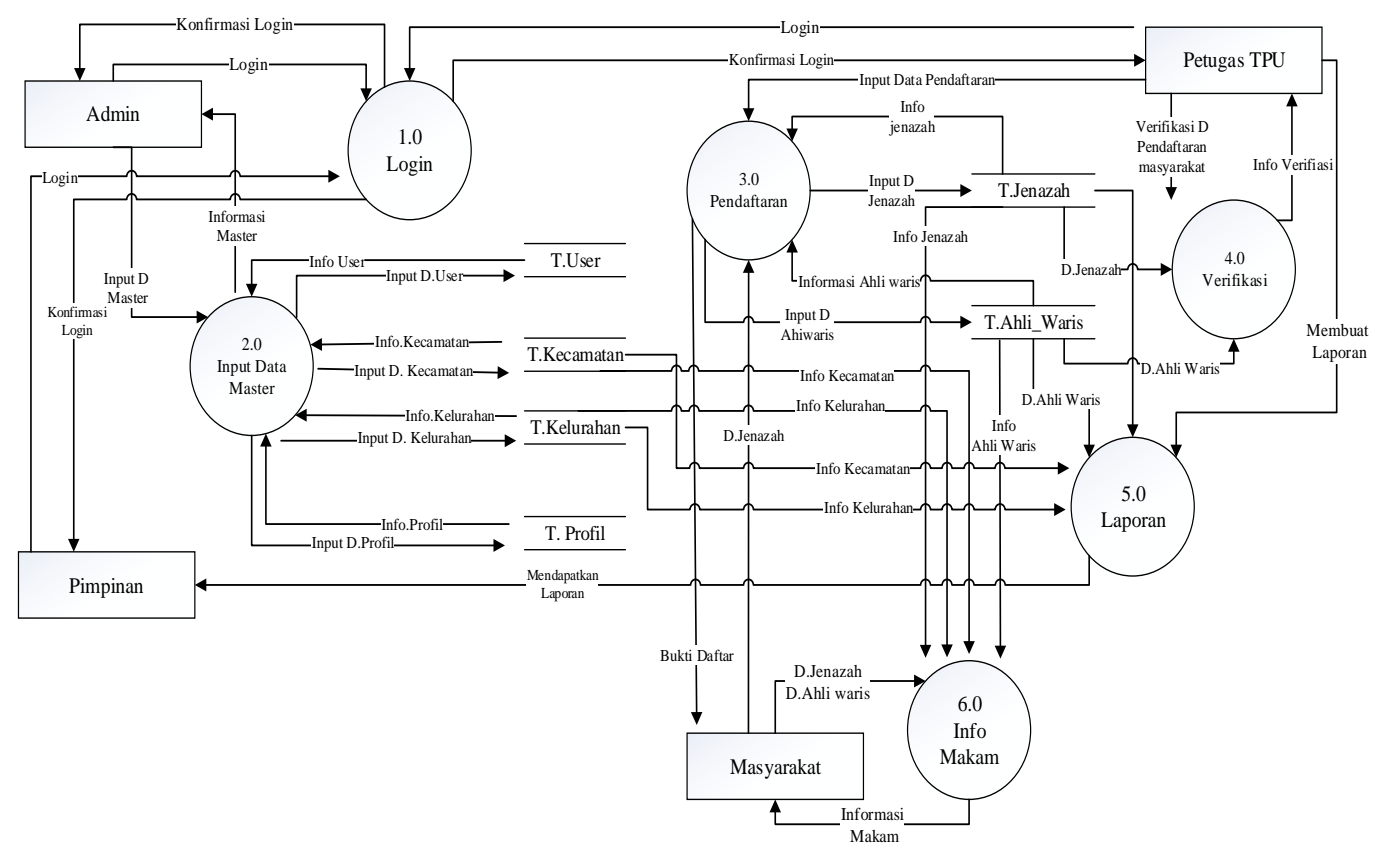

Gambar 5 DFD Level 0 
3. DFD Level 1 ( Proses 2.0 ) Manajemen Data Master

Penjabaran proses 2.0 (Rekam Data

Master) yaitu sebagai berikut:

a. Proses 2.1

Proses 2.1 merupakan proses rekam data user yang inputannya berupa data user serta output yang dihasilkan berupa data yang telah dikelola.

b. Proses 2.2

Proses 2.2 merupakan proses rekam data Kecamatan, yang inputannya berupa data kecamatan di Kabupaten Merauke. Output yang dihasilkan adalah data yang telah dikelola.

\section{c. Proses 2.3}

Proses 2.3 merupakan proses rekam data kelurahan yang inputannya berupa data kelurahan serta output yang dihasilkan adalah data yang telah dikelola.

d. Proses 2.4

Proses 2.4 merupakan proses rekam data profil kantor atau UPTD (Unit Pelaksana Teknis Daerah) yang inputannya berupa data kantor. Output yang dihasilkan adalah data yang telah dikelola.

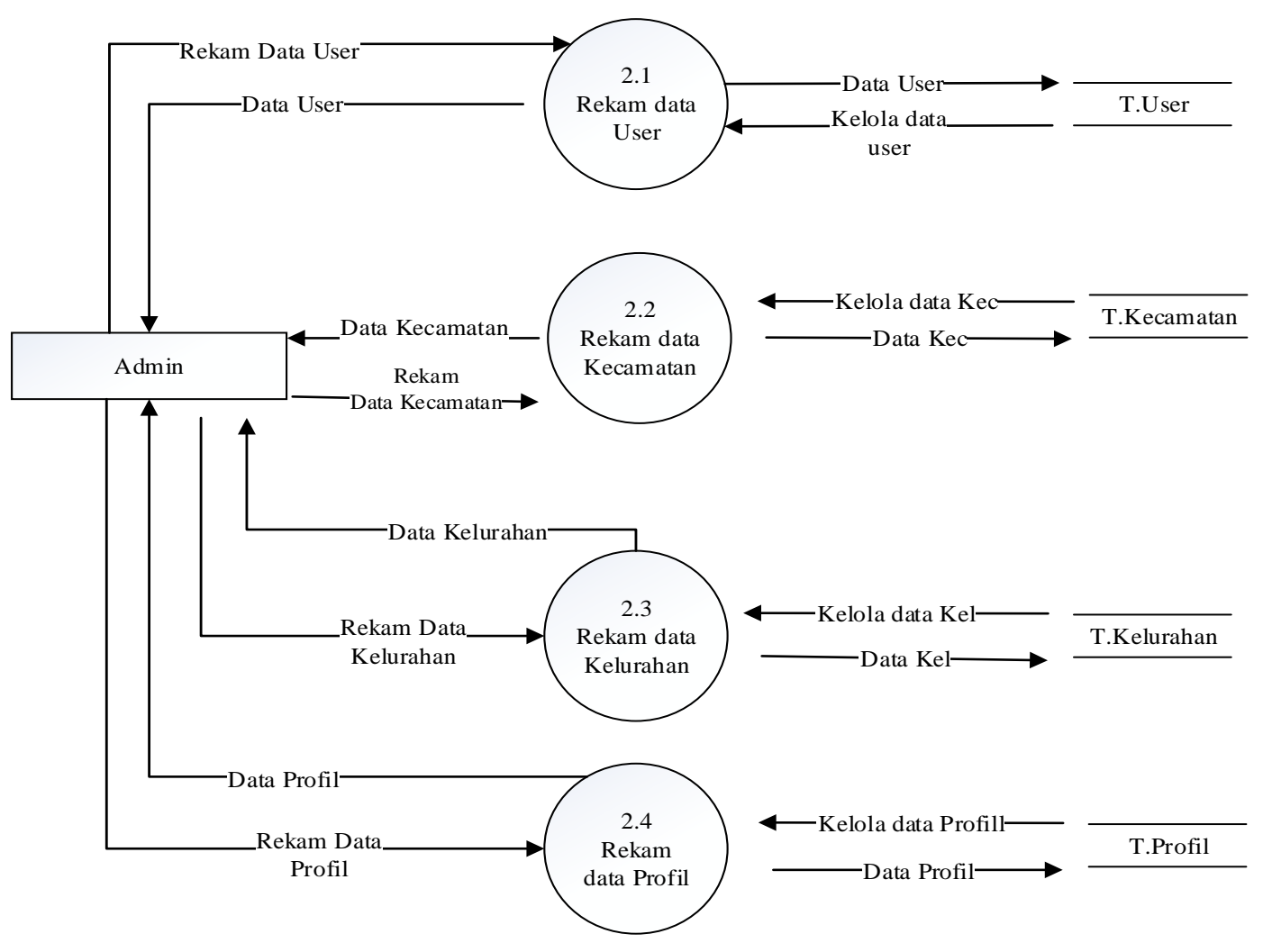

Gambar 6 DFD Level 1 ( Proses 2.0) 


\section{HASIL DAN PEMBAHASAN}

Tahapan implementasi merupakan tahapan yang menerjemahkan hasil perancangan berdasarkan analisis dalam penerapan perangkat lunak pada keadaan yang sesungguhnya. Implementasi antar muka ( Interface) dari perangkat lunak dilakukan perancangan yang telah dilakukan berdasarkan perancangan yang telah dibuat.

\section{Halaman Login}

Halaman ini admin, petugas atau pimpinan melakukan proses login dengan menginputkan username dan password yang kemudian akan diverifikasi oleh sistem sebelum masuk ke halaman berikutnya. :

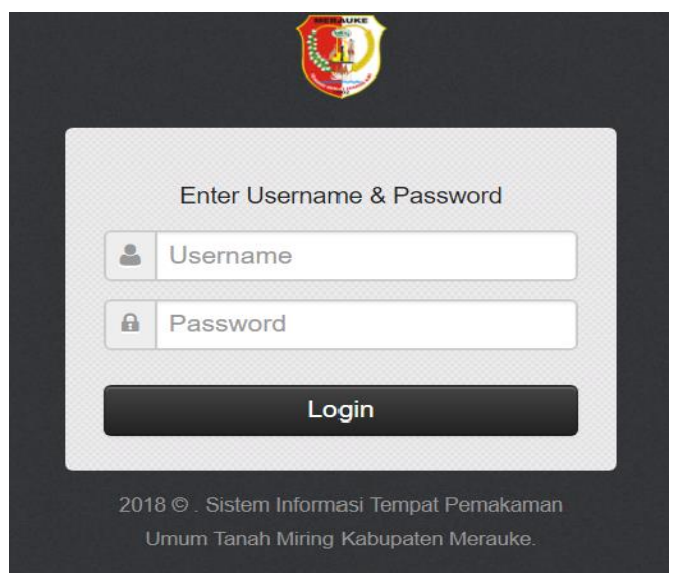

Gambar 7 Halaman Login

Halaman ini masyarakat atau client melakukan proses pendaftaran makam dengan cara menginput data jenazah kedalam sistem, dan sistem akan memberikan bukti daftar kepada masyarakat bahwa telah melakukan pendaftaran.

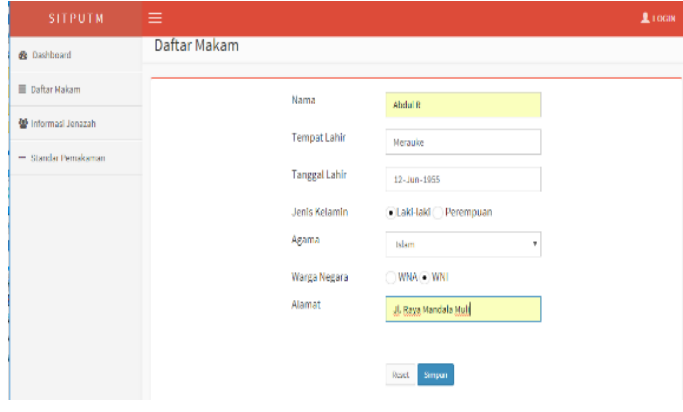

Gambar 8 Halaman Daftar Makam

3. Halaman Informasi Jenazah

Halaman ini dapat diakses oleh masyarakat dan petugas untuk mengetahui mencari informasi jenazah atau data makam.

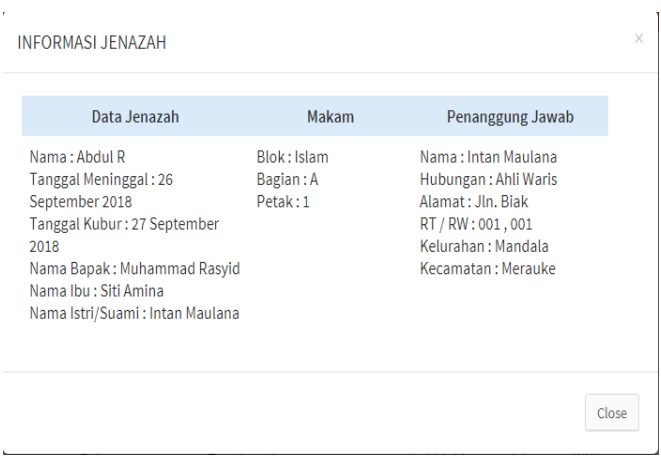

Gambar 9 Halaman Informasi data jenazah

4. Halaman Verifikasi

Halaman ini diakses oleh petugas untuk melakukan proses verifikasi pendaftaran makam yang telah didaftarkan oleh masyarakat atau client.

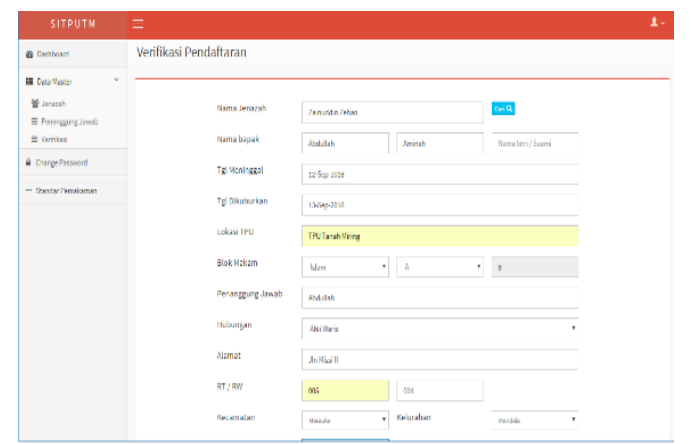

Gambar 10 Halaman Verifikasi Pendaftaran 
5. Halaman Laporan

Halaman ini diakses oleh pimpinan untuk melihat laporan pemakaman.

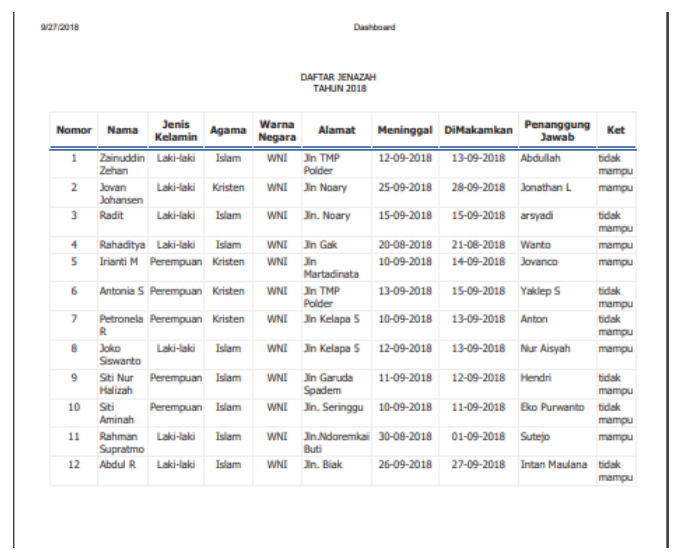

Gambar 11 Halaman Laporan

\section{PENUTUP}

\section{Kesimpulan}

Pengujian sistem menggunakan metode black box dan metode kuisioner pada sistem informasi tempat pemakaman umum Tanah Miring Kabupaten Merauke menunjukan kelayakan implementasi sistem. Maka kesimpulan yang dapat diambil dari penelitian ini yakni:

1. Sistem yang dibuat dapat melakukan pendataan makam, serta menampilkan informasi makam serta memberikan fasilitas pencarian data makam dan informasi pelayanan makam di TPU Tanah Miring.

2. Hasil yang diperoleh setelah melakukan pengujian sistem menggunakan metode kuisioner. Dari sisi admin responden menyatakan $40 \%$ sistem yang dibuat sangat baik, $60 \%$ responden menyatakan baik dan $0 \%$ responden menyatakan cukup dan kurang. Sedangkan dari sisi pengguna (masyarakat) responden menyatakan $43 \%$ sistem yang dibuat sangat baik, $37 \%$ responden menyatakan baik dan
20\% responden menyatakan cukup.

Dari sisi petugas responden menyatakan bahwa 52\% sistem dibuat sangat baik, $40 \%$ responden menyatakan baik, $8 \%$ responden menyatakan cukup. Dari sisi pimpinan responden menyatakan $60 \%$ sistem dibuat dengan sangat baik, $40 \%$ menyatakan baik.

\section{Saran}

Sistem Informasi Tempat Pemakaman Umum Tanah Miring dibuat untuk membatu masyarakat dalam melakukan pendaftaran makam, serta pencarian data makam, karena itu untuk mengembangkan dan menyempurnakan sistem lebih lanjut dapat disarankan: Sistem dapat dikembangkan oleh peneliti selanjutnya dengan menambahkan fasilitas berupa letak posisi makam dengan menggunakan titik koordinat.

Sistem yang digunakan pada penelitian ini yaitu berbasis web dan sesuai perkembangan teknologi maka sistem dapat dikembangkan menjadi berbasis smartphone (Android).

\section{DAFTAR PUSTAKA}

[1] Malisa Zainal, Irwansyah, 2012, Sistem Informasi Geografis TPU di Wilayah Palembang.Jurnal ilmiah Matrik Vol 8, No 3, Palembang.

[2] Sofian Ezra, 2015, Rancang Bangun Sistem Informasi Dalam Layanan dan Pemetaan Lokasi Pemakaman Pada Pemakaman Umum di Wilayah Jakarta, Jurnal ESQ I i-4 Volume 1, No.1, ISSN:2442-8337.

[3] Sri Winarno, Aditya Eka Prasetyadi, 2015, Rancang Bangun Sistem Pendataan Pemakaman Pada UPTD Kembang Arum Kecamatan Semarang Barat Berbasis Web, Jurnal ilmu sosial Vol 7, No 5, Semarang. 
[4] Novianti, Sandi 2015, Perancangan Sistem Informasi Pelayanan Pemakaman. Jurnal STIMIK Vol 23, No 4, Bandung.

[5] Krismaji. 2015, Sistem Informasi Akuntansi, Unit Penerbit. Yogyakarta.

[6] Dahlan Abdullah, 2015, Perancangan Sistem Informasi Pendataan Siswa SMP Islam Swasta Darul Yatama Berbasis Web, Jurnal IJNS, Volume 4, No.1 Januari 2015, ISSN 2302-5700.

[7] Luqman Muhammad, 2013, Pembangunan Sistem Informasi Manajemen Surat Masuk dan Keluar pada Bagian Umum Sekretariat Pemerintah Kabupaten Pacitan, Jurnal sentral penelitian engineering \& Edukasi, Volume 5, No.3 Tahun 2013. 